\title{
The analysis of the balanced development problem of China Tourism service trade
}

\author{
Lu Xiao-jin ${ }^{1}$, Hu Hui-min ${ }^{2}$ \\ ${ }^{\mathbf{1 , 2}}$ Guilin institute of tourism
}

\begin{abstract}
Under the situation of trade deficit of tourism trade in service, the scale of the deficit and the lost of national foreign currency exchange are increasing in direct proportion in China. It is a pseudoproposition that balances China's international payment via the deficit in the trade of travel services. Nowadays, China is at a crucial period of transformation and upgrade in foreign trade structure. Tourism service trade meets the goal of the structure upgrade. At the present stage, china should insist the balanced development of tourism service trade.
\end{abstract}

Key words: tourism service; trade deficit; balance development

Tourism service trade is one of the pillar industries in china's service trade. According to "the tourism competitive report" released by the World Economic Forum in 2011, China's natural resources is ranked fifth place in the world. China had kept the situation that imports of tourism exceeded exports of tourism until 2009. Tourism service trade began to appear deficit since China's economic policy emphasized the role in boosting domestic demand. The size of deficit reached \$24.1 billion, which accounts for $20 \%$ of the tourism service trade. Therefore, the imports and exports of tourism are in an unbalance state. According to "the annual report of china outbound tourism development 2012" released by the China national tourism administration, the deficit will expand to $\$ 33$ billion. The tourism service trade is facing the trend of rapid growth year by year. This phenomenon did not attract government enough attention. The author thinks that the rapid expansion of the deficit in the trade of travel services should cause our high vigilance.

\section{The national exchange cost in the situation of the deficit in the trade of travel services}

At present, China's exports of tourism grow slowly. The scale of tourism services trade mainly relies on the growth of the imports of tourism. According to the author's analysis, there are system deficiencies which exist in China's current foreign trade policies. The deficit in the trade of travel services will cause the loss of national interests, and generate the diseconomies consequences of scale of tourism services trade.

Analyzing the situation of China's international balance of payment, we can find that China has deficit in the service trade and surplus in capital project. However, the international fund holders will take money out from China ultimately. At the same time, "hot money" flows into China. Ultimately, the international speculator will withdraw more and more foreign currency as appreciation of the RMB. The deficit in the trade of travel services will cause the shortage of foreign exchange. The shortage of foreign exchange will be supplemented via the surplus in goods trade. In goods trade, industry 
products account for $90 \%$ of total export. These exporters will get export -tax refund from China after the industry products have been exported to other countries. China buys the foreign exchange from the exporters. Therefore, the actual cost is higher than the exchange rate quoted by the State General Administration of Exchange Control of the People's Republic of China.

We assume that the exchange rate is RMB6.25/USD, and the exporter's cost of foreign exchange is RMB6.20 per U.S. dollar. At present, the export-tax rebate rate of ordinary industrial products is $13 \%$. According to the export-tax rebate rate, the computational formula of tax refund is: Tax refund $=6.2 \div 1.17 \times 13 \%=0.69$ (RMB)

After receiving the payment, exporters will sell the foreign currency to state according to the foreign exchange rate. China buys US dollars from exporters according to the foreign exchange rate of 6.25 Yuan per U.S. dollar. On the other hand, China pays export -tax refund to exporters as well. Therefore, China actually spends RMB 6.94 to buy one US dollar. Outbound tourist buys US dollars from bank of China according to the foreign exchange rate of 6.25 Yuan per US dollar. If the deficit appeared in tourism service trade, the deficit would be supplemented via the surplus in goods trade. When outbound tourist buys one US dollar from China, China will suffer a loss of 0.69 Yuan. In other words, outbound tourists can obtain 0.69 Yuan subsidies when they buy one dollar form China.

Shown in Figure 1, if the deficit in the trade of travel services partly gets foreign exchange from trade surplus in goods, China's actual cost of the purchase of U.S. dollars (6.94 Yuan / dollar) is higher than the national price of the selling dollars (6.25 Yuan / dollar). The gap between China's actual cost of purchase of US dollar and the national price of selling US dollar is equal to the national tax subsidies which are given to goods exporter. Therefore, it creates loss (shown in the shaded part). The deficit in the trade of travel services and the lost of national foreign currency exchange are increasing in direct proportion. In other words, the country would generate exchange loss when tourism service trade began to appear deficit. In fact, the loss is a kind of subsidy to outbound tourist. And this state subsidy is targeted subsidy which is only obtained by outbound tourist. Most of the residents will lose the chance to obtain the subsidy as they haven't economic capacity to pay for expenses of outbound travel. The larger the deficit in the trade of travel services, the more wealth will be transferred to the outbound tourists. In the year of 2011, the deficit in the trade of travel services was $\$ 24.1$ billion. According to the state exchange losses, china formatted the exchange loss of 16.6 billion Yuan. In other words, state subsidies given to outbound tourists had reached 16.6 billion Yuan. As most of outbound tourists are social high-income peoples, they have strong consumption ability. The tendency of outbound tourism is further strengthen under the policy of national foreign trade (because they can buy US dollar in lower price). And with the growth of China's per capita GDP, the potential demand of outbound tourism is expanding. The consumptions of outbound tourism are expected to increase. In addition, outbound tourists shopping abroad can also enjoy duty-free shopping policy. Therefore, China's outbound tourists can enjoy double subsidies. The double subsidies became the catalyst for China's upsurge of out-bound tourism (outbound tourists receive government subsidies by purchasing foreign exchange in china, and enjoy foreign duty-free shopping policy at overseas. 


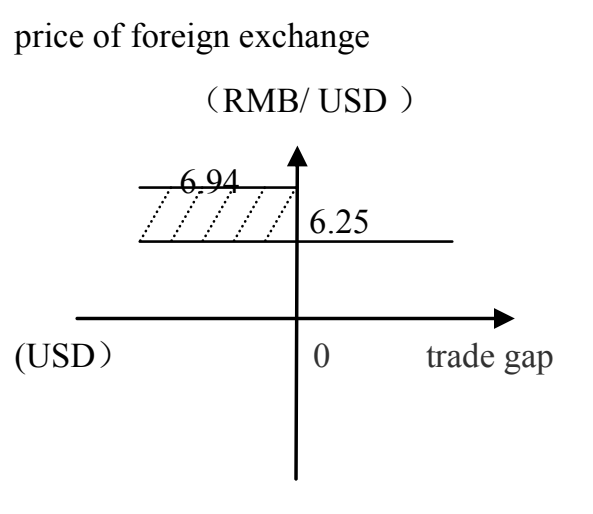

Figure 1

On the other hand, the China's tourism companies which operated the business of inbound tourism sold their foreign exchange earnings from international tourism in accordance with the state official foreign exchange rate, and did not get the country's export- tax rebates. These companies settled accounts with overseas travel agency by using US dollar.Therefore, the tourism companies' policy cost is $11 \%$ higher than the policy cost of goods trade. Foreign tourists can only enjoy the duty-free shopping policy when they shop in Hainan. Therefore, foreign tourists' shopping enthusiasm in China was severely inhibited. That's one of the reasons why the average spend of inbound tourist is not high.

According to the China's current foreign trade policy, the imports of tourism service can obtain potential subsidies from China but the exports of tourism service can't. Therefore, this is an asymmetric system arrangement. It becomes the important reason that outbound tourism is increasing in high speed and the inbound tourism has become stagnant. This is a system defects. If the foreign trade's system defects wouldn't be corrected, the imbalance of trade in tourism service will become more and more serious.
2. It is a pseudo-proposition that balances the international payment via deficit of trade in tourism service

According to an academic viewpoint, the balance of the international payments via deficit in the trade of travel services which can help to reduce trade friction, slow the pressure of RMB appreciation, and create a favorable external environment for China's foreign trade. In response to the downturn of the international market since the international financial crisis, China has taken the way of stimulating domestic demand as the main means of economic growth. Therefore, the role of foreign trade in boosting the economy is beginning to weaken. And the existence of large number of goods trade surplus, country has misgiving about encouraging the exports of tourism. Therefore, the inbound tourism has the trend of being marginalized. The rapid expansion of the deficit in the trade of travel services seems to be practicing the statement "the balance of goods trade surplus via the deficit in the trade of travel services".

\subsection{The practice of balancing the inter- national payment via deficit in the trade of travel services does not coincide with scientific development view}

China's surplus in goods trade is created because China is at the low end of the industrial chain, and has a lot of processing trade. China's surplus in goods trade is also the results of the multinational company's industrial transfer, production internationalization and the value chain control. It is China's position arrangement of economic globalization. We should suit the remedy to the case, and get rid of the vassal arrangement of our country's trade structure via the western developed countries. We should take the strategy of industrial structure advancement and upgrade the industrial structure from 
secondary industry to tertiary industry gradually. We should gradually realize the industry chain transfer from low-end to high-end in the international division of labor, develop general trade and reduce the proportion of processing trade. And the practice of reducing the trade surplus in goods via deficit in the trade of travel services is to use the low value- added export products to substitute the high value-added export products. It is to use low-end trade industrial structure to alternate high-end trade industrial structure and use low efficiency to alternate high efficiency. This practice would work against the strategy of industrial structure advancement and run counter to the development rules of market economy and the country's long-term interests. Therefore, it is a pseudo-proposition that China balances the international payment via the trade deficit of tourism trade in service.

\subsection{The external environment can't be improved via deficit in the trade of travel services}

In international trade, competitors often protect their own interests by using the trick of international trade friction when their own interests are threatened. In order to obtain more interests, the developed countries use international trade friction to delay the backward countries' economy development and keep its leading position in the world. So long as there are places for competition, the conflict of interest exists. Therefore, there will be trade friction. The trade friction between the countries is the normality of the international market competition and is not able to be solved simply by addition and subtraction on the balance of payment. We should use the international trade rules to safeguard our legitimate rights and interests. We should continue to enhance the international influence, take an active part in instituting international trade rules, resolve trade frictions through the market mechanism and the win-win principle, and reduce external costs. The way of giving up own interests, damaging national economy and making compromise that does nothing to solve the trade friction problems. In fact, the beneficiaries of tourism service trade are the exporting countries' tourism industry. In situations in which the country has the deficit in goods trade, the industries where exist inverse production have no direct access to get subsidies and get little benefits from the surplus of tourism service trade. These enterprises' demands haven't been met. So they will still ask their government to put pressure to their competitors that do harm to their interests. The international trade friction will not be avoided. Therefore, we can't reduce the trade fiction and obtain a favorable international economic environ -ment by utilizing the deficit in the trade of travel services to reduce the surplus in goods trade. That won't do us any good though.

The practice of improving the external environment of foreign trade via deficit in the trade of travel services is futile. China's deficit in the trade of travel services in 2011 has reached \$ 24.1 billion. In the first half of 2012, China's outbound tourism grew $19 \%$ of total, while inbound tourism declined year on year. The scale of deficit in the trade of travel services will be further expanded and it is unable to be reversed. "China's Foreign Trade Situation Report (Fall 2012)" issued by Ministry of Commerce shows that the number of trade remedy investigations against China's export products is 55 , an increase of $38 \%$, in the first three quarters of 2012. The amount of money involved is increased nearly eight times than before. The situation of trade friction is becoming more serious. At the same time, the pressure of RMB appreciation still remains. In Nov.2012, the renminbi's spot 
exchange rate did not hit a daily limit only in the day of 16 and 21 . The rest of 20 trading days, the renminbi's spot exchange rate had ever reached the daily limit position. China has imported great amount of tourism service trade. But there is no sign of improvement in the external environment of China's foreign trade. In Sep. 1987, Japan launched a "Ten Million Programme" to double outbound tourist departures from 5 million to 10 million between 1986 and 1991. At that time, Japan's industrial structure was in the world's advanced level as Japan had become an economic power. Japan's outbound tourism was become a mass consumption. Japan tried to expand outbound tourism scale and quell international economic disputes through using the deficit in the trade of travel services to balance the international balance of payments. The practice was not only failed to prevent the appreciation of Japanese yen, but also ushered economic stagnation in a long-term. Japan is still difficult to get rid of the predicament. As the result, we can find that it is unrealistic to ease trade friction via the deficit in the trade of travel services.

\section{The Chinese benefit of the balanced development of import and export trade in tourism services}

\subsection{The balanced development of imports and exports trade in tourism services will be conducive to the sustainable development of tourism industry.}

Inbound tourism can earn foreign exchange for the country, generate revenue, bring the employment opportunities and enhance the quality of tourism products. Inbound tourism can also promote the development of related industries, promote the growth of national income, and lay the economic foundation for citizens' outbound travel. The outbound tourism can provide people with the exotic tourism product, broaden people's horizons, enhance people's quality life, bring a spirit of joy for people, and promote economic and cultural exchanges with countries around the world. The rapid development of outbound tourism without the support of inbound tourism, will result in the loss of social wealth, cause the blood loss multiplier effect on our economy, damage China's economic development, and ultimately affect the continuing development of the tourism service trade. Some scholars argue that the multinational operation of tourism enterprises can reduce the loss of wealth. But only several China's tourism enterprises have the multinational operation ability. Tourism industry is labor-intensive and resource-dependent industry. If a country with tourism resources kept the monopoly on the tourism resources, multinational tourism enterprises would have difficulty to transfer wealth to their home country. So, the reduction of the wealth loss via multinational operation is really been just a theoretical thing until now. Therefore, the balanced development of imports and exports trade in tourism services will be conducive to the sustainable development of tourism industry.

\subsection{The balanced development of import and export trade in tourism services will be conducive to the transformation and upgrad- ing of foreign trade}

China is now in the key period of fast economy development. With the development of the national economy and the growth of people's income, the original mode for growth - depending on low labor costs to exchange for economic growth - may not work much longer. As China is losing the advantage of demo- 
graphic dividend gradually, labor costs in China are rising. The overall economy has entered into a stage of the increase in the cost of essential factors of production. Since 1996, the processing trade has occupied the half of China's foreign trade. However, China's labor cost advantage is losing gradually. In order to achieve maximum benefit, multinational companies are gradually transferring the laborintensive industries to the countries with lower labor costs. China should accelerate structural readjustment, industrial restructuring and upgrading. Tourism industry is a strategic industry which is able to drive the development of national economy, push the upgrading of the industrial structure, provide more employment opportunities and bring social benefits.

Therefore, China should take the improvement of the competitiveness of tourist service trade as the cut-in point to achieve a balanced development of inbound and outbound tourism, expand the scale of tourism service trade, and improve the place of tourism service trade in China's foreign trade structure.

\subsection{The balanced development of import and export trade in tourism services will be conducive to making China be the tour po- werful nation}

Tourism industry is the labor-intensive industries which highly dependents on resources. But tourism industry's dependence on technology is relatively low. Compared with other service industries with high technology dependence, china has a comparative advantage of tourism resources and labor cost. Therefore, China has greater chance to be the tour powerful nation because the object of making China be the tour powerful nation required a relatively low cost and difficulty. Comparing with competitors, China' tourism companies have a great gap in brands, channels, marketing, management models and business philosophy. In order to enhance the international competitiveness in the travel services industry, China's tourism companies should spend a lot of money on products' research and development, the construction of the international market brands, channel development and the cultivation of high-end international market. As tourism service industry requires finance investment, the huge loss of social capital caused by the rapid expansion of tourism service trade deficit is a great waste of resource. The outbound tourism could be seen as the fashion trend of the pursuit of highquality life by high-income people. This might lead to the formation of concept that national tourism products are the low-end products. This concept is not conducive to the construction of China's tourism brand and tourism industry's health and long-term development. In fact, the potential huge outbound tourism market in China is also a kind of strategic resources. We can take the cooperation approach that we use outbound tourism market to exchange inbound tourism market. The cooperation approach can help us to achieve a simultaneous growth of inbound and outbound tourism, expand the scale of tourism services trade, and achieve the object of making China be the tour powerful nation.

\section{Summary}

In conclusion, the deficit in the trade of travel services is not in China's economic interests.

China should strive to reverse the development trend of the deficit in the trade of travel services, take various measures to guide tourism service trade to the balanced development. Firstly, China should reform its foreign trade system, overcome the system defects of 
the inhibition of tourism services exports and encouraging imports, make policies to encourage tourism services exports, make export rebates policy for tourism services trade and promote policies of foreign tourists shopping departure tax rebate as soon as possible. Secondly, China's long-distant outbound tourism is a kind of luxury consumption according to China's current consumption level and stage of economic development. We can levy upon the similar imported luxury goods' consumption tax to China's longdistant outbound tourism. This approach can inhibit irrational consumption of outbound tourism. On the other hand, we can use the tax revenue to develop the inbound tourism products and market. We should improve the international competitiveness of inbound tourism, raise development money for the expansion of the size of the exports of tourism services, further reinforce the basis for the development of inbound tourism and promote coordinated and balanced development of import and export trade in tourism services. In addition, we should give full play to the strategic role of China's outbound tourism market and take the cooperation approach that we use outbound tourism market to exchange inbound tourism market in foreign economic cooperation. The cooperation approach can help us to achieve win-win situation in foreign economic cooperation, and promote the balanced development of the import and export trade of China's tourism services.

\section{References:}

[1] Zhang Ling-yun,,Yang Chen, "From Giving Prominence to Foreign Exchange Earnings to Balance of Payment:Rethinking about the Developing Strategy of Chinas Outbound Tourism"[J]. Tourism tribune, pp.2024,2007,(6).

[2] Yang Jun, "Economic Analysis On Outbound Travel and Tourism Transnational Operation" [J].Journal of Guilin Institute of Tourism, pp.281285,2006, (6).

[3] Lu Xiao-jin, "The analysis and ponder on tourism service trade deficit of China" $[\mathrm{J}]$.China business \& trade, pp.144-146,2012,(23) .

[4] Dai Xue-feng, WANG Dong-gui, "Viewing the Policy of the Development of China's Outbound Tourism from the Constitution and Nature of Foreign Exchange Reserve" [J].Tourism tribune, pp.24-28, 2008,(12).

[5] Lei Ping, Shi Zulin, “ An International Comparative Study on Development Level of China's Outbound Tourism" $[\mathrm{J}]$. Tourism tribune, pp.3337,2008,(2).

[6] Dai Xue-feng, WU Ning, “ An Analysis of Negative Impact of the Rapid Growth of China's Outbound Travel" $[\mathrm{J}]$.Tourism tribune, pp.4145,2006,(2).

[7] Zhang Jia-qing, Tan Peng-cheng, "Analysis of Influence Factor in China's Tourism Service Trade"[J]. Ecological economy, pp.155157,2009,(1). 